\title{
SUSTENTABILIDADE NA MODA COM BASE NOS FUNDAMENTOS DO BIOCENTRISMO E DO VEGANISMO
}

\section{NEIDE KÖHLER SCHULTE, Dra. | UDESC}

\section{INTRODUÇÃO}

A questão central desse estudo é verificar como os fundamentos da ética ambiental biocêntrica e a proposta do veganismo, podem contribuir na reflexão sobre mudanças no sistema da moda diante do paradigma da sustentabilidade, de modo que, as roupas cumpram sua função como vestimenta, expressão estética e de identidade, porém, com menos danos socioambientais.

O pressuposto é que a proposta do veganismo e da ética ambiental biocêntrica oferecem fundamentos para um modo de produção e de consumo mais compatíveis aos príncipios da sustentabilidade e para um modo de vida que seja menos destrutivo.

De acordo com os pressupostos da ética ambiental biocêntrica o mundo natural não é um simples objeto para ser explorado pelos humanos, nem as criaturas utilizáveis como recursos de nosso uso e consumo. Ao contrário, as comunidades de vida selvagens são merecedoras de preocupação moral e consideração pelos humanos, pois possuem um tipo de valor que pertence a elas inerentemente (TAYLOR, 1989);

Auto-defesa, permite aos agentes morais se protegerem contra organismos danosos ou perigosos, destruindo-os, caso necessário. Proporcionalidade, diz que em um conflito entre valores humanos e o bem de animais e plantas silvestres, maior peso deve ser dado aos interesses básicos (por exemplo, a sobrevivência). Mal menor, se aplica em situações em que os interesses básicos de animais e plantas estejam inevitavelmente em competição os interesses não básicos de humanos e que a satisfação desses interesses humanos seja prejudicial para os outros seres. Justiça distributiva, o critério é a justa distribuição dos bens garantidores de satisfação dos interesses das partes em conflito, quando todos os interesses são básicos, portanto de igual importância para os envolvidos. Justiça restitutiva, se aplica para repor aquilo que foi prejudicado aplicando-se os princípios anteriores, buscando o bem de todo um ecossistema, para poder atingir o maior número possível de seres.

$O$ termo veganismo surgiu no século $X X$ e é o mesmo que vegetarianismo estrito, ou vegetarianismo profundo. Veganos não consomem nenhum produto de origem animal, nem fazem uso de animais para trabalho, experimentação, entretenimento, entre outros. Procuram reduzir os danos à natureza (CALLICOTT, 1985).

\section{OBJETIVO}

O objetivo desta pesquisa é analisar como os fundamentos propostos pela ética ambiental biocêntrica e pelo veganismo podem trazer uma base para a reflexão sobre a importância de mudanças no sistema de moda, para que seja mais compatível à sustentabilidade.

\section{OBJETIVOS ESPECÍFICOS}

- Levantar o estado da arte e os conceitos sobre moda, sustentabilidade ambiental, ética ambiental biocêntrica e veganismo;

Apresentar a proposta para a ética ambiental biocêntrica e estabelecer uma relação com o estilo de vida dos veganos;

Entrevistar consumidores veganos que, segundo seu discurso, já praticam um consumo mais ético e sustentável, para verificar o seu modo de consumo;

Durante o trabalho foi possível identificar uma convergência no discurso entre os teóricos da ética ambiental biocêntrica, dos veganos, e de pesquisadores da sustentabilidade ambiental quanto à necessidade de mudanças no sistema de valores éticos. Essas mudanças de valores terão impacto direto nas ações humanas e um desenvolvimento sustentável não parecerá algo forçado como atualmente, será algo natural. São dados exemplos dessas ações: consumir menos, ter critérios (produtos sustentáveis) na hora da compra, cuidar mais dos produtos, encaminhá-los no pós-uso (ciclo de vida fechado), entre muitas outras ações desejáveis para um modo de vida sustentável.

\section{REFERÊNCIAS}

CALLICOTT, Baird. Intrinsic Value, Quantum Theory, and Environmental Ethics. In: ENVIRONMENTAL ETHICS. Fall 1985, v. 7, n. 3, p. 257-275.

TAYLOR, Paul W. Respect for Nature: a theory of environmental ethics. 2. impress with corrections. New Jersey, Princeton: Princeton University Press, 1987. 
